Geological Society, London, Special Publications

Carbonate-siliciclastic sedimentation on a high-energy, ocean-facing, tropical ramp, NE Brazil

Viviane Testa and Dan W. J. Bosence

Geological Society, London, Special Publications 1998, v.149; p55-71.

doi: 10.1144/GSL.SP.1999.149.01.05

Email alerting

service

Permission request

Subscribe click here to receive free e-mail alerts when new articles cite this article

click here to seek permission to re-use all or part of this article

click here to subscribe to Geological Society, London, Special Publications or the Lyell Collection

\title{
Notes
}

(C) The Geological Society of London 2013 


\title{
Carbonate-siliciclastic sedimentation on a high-energy, ocean- facing, tropical ramp, NE Brazil
}

\author{
VIVIANE TESTA ${ }^{1} \&$ DAN W. J. BOSENCE ${ }^{2}$ \\ ${ }^{1}$ Centro de Pesquisa em Geofisica e Geologia, Universidade Federal da Bahia, Rua \\ Caetano Moura, 123, Salvador, Ba 40210-340, Brazil \\ ${ }^{2}$ Department of Geology, Royal Holloway University of London, Egham TW20 0EX, UK
}

\begin{abstract}
The inner portion of the continental shelf of Rio Grande do Norte State, Brazil has been investigated by Landsat-TM imagery and by scuba diving. The area experiences high-energy, shoreline and shelf-margin parallel currents driven by a combination of oceanic, tidal and wave processes. The high meso-tidal range $(<4 \mathrm{~m})$ further distributes the high-energy waters over the entire inner shelf region $(0-25 \mathrm{~m})$. This shelf is a high-energy, distally steepened ramp in which the distribution of carbonate and siliciclastic facies belts is controlled by the energy of the environment, the sources of siliciclastic sediment and the Quaternary history of the area. Carbonate sediments are generated throughout the sublittoral zone and are dominated by calcareous red and green algae. Small, low-diversity coral patch reefs occur in shallow areas. Quartz-rich sands form beaches and subaerial longitudinal dunes, and an offshore, submarine, sandstone outcrop interpreted as a former Quaternary shoreline. This sandstone has been eroded during the Holocene transgression to generate quartz sands deposited in a train of transverse dunes migrating parallel to the coast. Longitudinal sand ribbons comprising bioclastic gravelly sands attest to high-energy, shore-parallel currents in the inner shelf. Branching coralline algae (maërl) form stabilized sea-floor areas. Preliminary ${ }^{14} \mathrm{C}$ dating indicates a Pleistocene highstand period when coarse algal sands accumulated. Holocene lowstand conditions spread quartz-rich sands over the inner ramp area, which were reworked during the Holocene transgression. Present-day erosion, transport and in situ carbonate production results in mixing of these earlier carbonate and siliciclastic units. The Brazilian ramp has similar, but narrower morphology, when compared with the distally steepened ramps of the Yucatan and west Florida. All three ramps are swept by coastline-parallel currents. In Brazil, the higherenergy, windward-facing, inner ramp has calcareous algal sands and patch reefs compared with the inner ramps of the leeward-facing Gulf of Mexico examples that accumulate molluscan sands. Outer ramp facies in each example are planktonic foraminiferal oozes.
\end{abstract}

The Brazilian continental shelf is narrow with a steep, fault-controlled continental slope inherited from the rifting of the Atlantic Ocean. The study area (Fig. 1) lies within the Touros High and Rio Grande do Norte Plateau of Northeast Brazil. These two structural highs are characterized by Precambrian basement with a thin cover of Cenozoic sediments (Asmus \& Porto 1973; Martins \& Coutinho 1981). The Cenozoic and Mesozoic sections thicken along this continental margin to the northwest into the Portiguar Basin and to the south into the Paraiba-Pernambuco Basin (Asmus \& Porto 1973; Figueiredo 1985; Mello 1989). This structural high is still tectonically active so that local fault-related sea-level changes are superimposed on Quaternary glacio-eustatic sea-level changes (Srivastava \& Corsino 1984; Suguio et al. 1985; Testa 1997; Bezerra et al. 1998).

The northeast Rio Grande do Norte shelf can be divided on the basis of its bathymetry into two regions. The inner shelf is a sub-horizontal to gently sloping shelf $\left(0.8-1^{\circ}\right)$, extending some
25-30 km from the shoreline to a topographic break at about $20 \mathrm{~m}$ depth marked by the Lithified Sediment Zone (Fig. 2). Seawards, the midto outer shelf has a moderate slope of around $5-15^{\circ}$, which continues until about $60-80 \mathrm{~m}$ depth at the outer Brazilian shelf margin, where the slope increases to $c .60^{\circ}$ and descends to oceanic depths (Fig. 1).

The Rio Grande do Norte continental shelf is an open ocean facing, windward shelf, with no bays, estuaries or significant inflowing rivers. The shelf is oriented to face the full strength of the westerly flowing South Equatorial Current (Fig. 1) and this, combined with high winds and a high tidal range, makes this a high-energy, open ocean facing shelf. The shoreline is characterized by beach-dune complexes of relict and reworked siliciclastic sands. Despite the equatorial, open-ocean setting the shallow-marine waters lack large reef systems, and are blanketed by a complex of mixed carbonate-siliciclastic sands and gravels composed mainly of calcareous red and green algae. Deep-water deposits

TESTA, V. \& BosenCE, D. W. J. 1998. Carbonate-siliciclastic sedimentation on a high-energy, ocean-facing, tropical ramp, NE Brazil. In: WRIGHT, V. P. \& BuRCHETTE, T. P. (eds) Carbonate Ramps. Geological Society, London, Special Publications, 149, 55-71. 


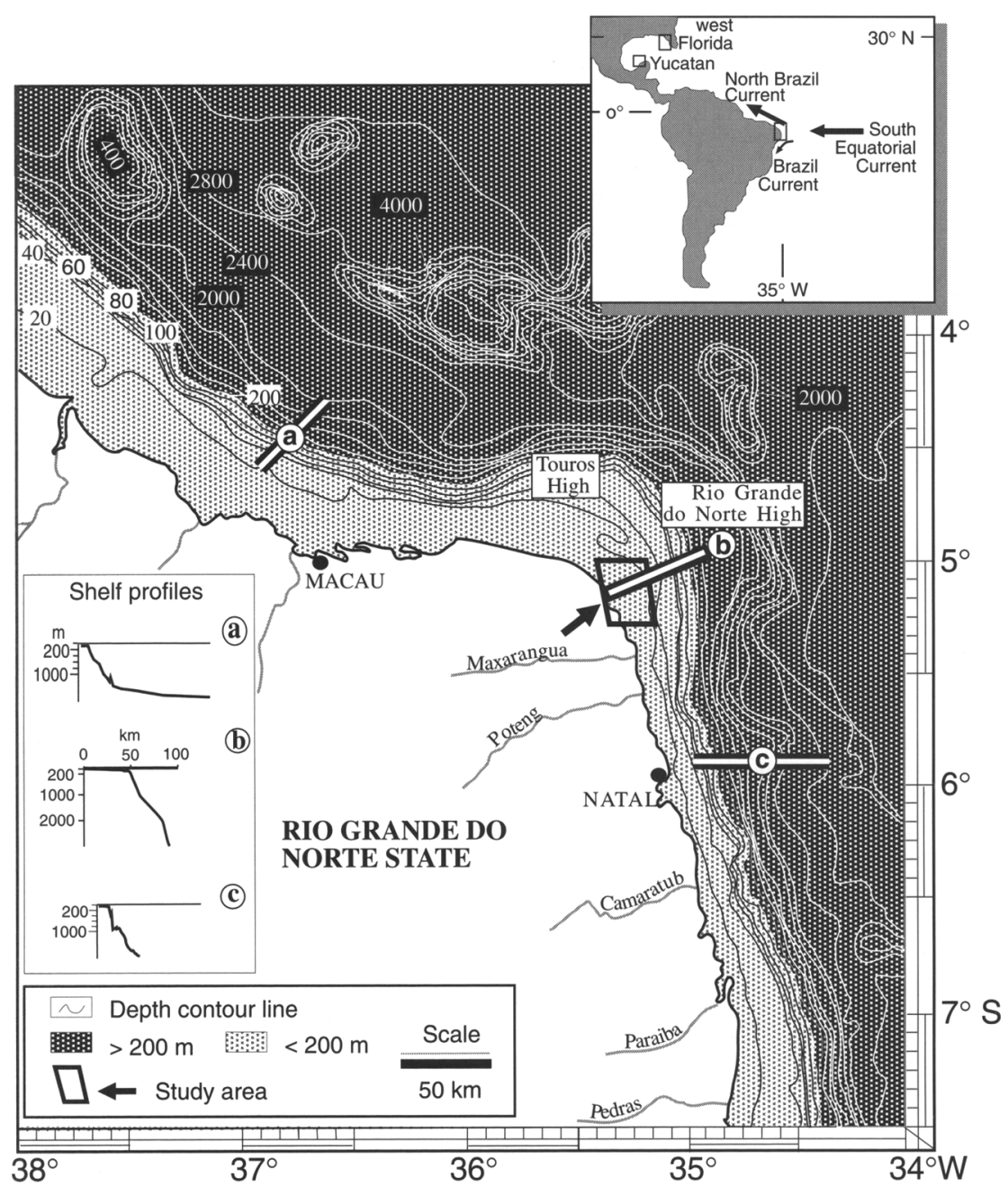

Fig. 1. Morphology of Northeast Brazil continental shelf and margin and location of study area (after Projeto REMAC: Margem Continental Norte 1979). Bathymetric profiles a, b and c after Martins \& Coutinho (1981). Inset summarizes western tropical Atlantic currents (after Richardson \& Walsh 1986).

consist mainly of a hemipelagic silty clay, rich in Foraminifera (Mabesoone \& Coutinho 1970; Mabesoone 1971; Francisconi et al. 1974; Milliman \& Summerhayes 1974; França et al. 1976; Martins \& Coutinho 1981; Testa \& Bosence 1998).

This low-angle, carbonate-dominated, continental shelf may therefore be categorized as a distally steepened carbonate ramp (type $\mathrm{G}$ of Read 1985; Burchette \& Wright 1992). Its morphology is similar to other Atlantic and Gulf of Mexico margins such as the Yucatan shelf (Logan et al. 1969), the western Florida shelf (Mullins et al. 1988) and the cool temperate northwest European shelf (e.g. Light \& Wilson this volume).

\section{Oceanographic regime}

The marine environment in the study area is characterized by high temperatures and salinities of surface waters. Sea surface temperature ranges from about $26.5^{\circ} \mathrm{C}$ in the winter to about $28.5^{\circ} \mathrm{C}$ in the austral summer (Servain et al. 1990). The salinity is also typical of equatorial and tropical environments, and varies between 36 and 37\%o. The coastal waters are nutrient depleted, with low suspended-sediment 


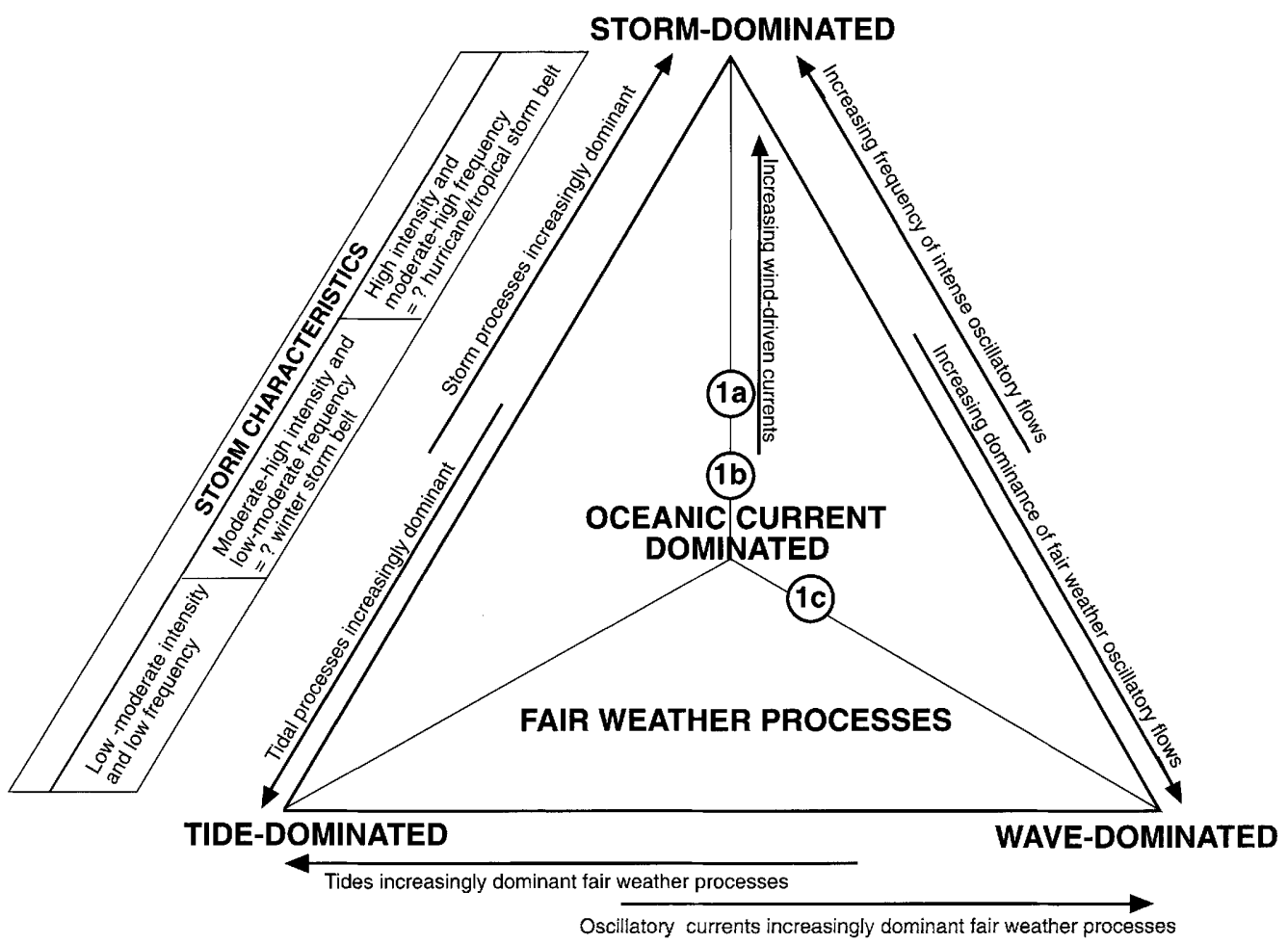

Fig. 2. Summary of the main types of offshore shelf depositional environments (from Johnson \& Baldwin 1996) based on relative dominance of storms, tides, oceanic currents and waves. The following plots are for different time periods on the Northeast Brazilian shelf: 1a, July-September wet season, when wind-driven currents are intensified by the movements of the Inter-Tropical Convergence Zone; 1b, dry summer season, when hydrodynamic energy results from combination of oceanic currents, tides and waves; 1c, austral summer season neap-tide periods, which occur twice a month and last for 1 week.

concentrations, because of the absence of large rivers discharging suspended sediments in the area.

This ramp is characterized by longshore currents and is strongly influenced by the North Brazil Current (NBC, 30-40 cm/s, Richardson \& Walsh 1986) (Fig. 1). Allied to this is a semidiurnal, high-mesotidal (2.0-3.5 m, Hayes 1979) regime. Because of the effects of the strong southeasterly winds (April minima of $3.6 \mathrm{~m} / \mathrm{s}$ and August maxima of $6.8 \mathrm{~m} / \mathrm{s}$, Servain et al. 1990) wave energy is moderate $(H=60-150 \mathrm{~cm}$, Hayes 1979) even during fair-weather conditions.

Three periods of high hydrodynamic energy are recognized in the area: (1) during July-September, currents are strengthened markedly by the movement of the Inter-Tropical Convergence Zone, which enhances the action of winds and currents in the area; (2) spring tides commonly coincide with 3-day periods with strong winds, and it is well known by local fishermen and from our diving observations that these lunar phases generate strong currents with increased water turbidity, in water depths of less than 15-20 m along the coast and up to $15-20 \mathrm{~km}$ offshore; (3) strong currents are also generated during periodic storms within the region. Therefore the shallower regions $(<30 \mathrm{~m})$ are reworked by a constant, high hydrodynamic energy regime for days or months at a time and all of the study area is regarded as above fair-weather wavebase and within the inner ramp zone of Burchette \& Wright (1992).

The high-energy setting results in coarsegrained, well-sorted sediments and bedforms, which are for most of the time in equilibrium with the hydrodynamic energy of the environment. Following Johnson \& Baldwin's (1996) classification of shelves in terms of hydrodynamic energy regimes, the area would be classified as an oceanic current-dominated, shelf (Fig. 2 ). However, depending on the time of year and 
the time scale of the observations, oceanic, wind and tidal currents will all have an important influence at different times of the year (Fig. 2).

This contribution introduces a case study of a present-day, open-ocean, equatorial ramp that is unusual in that it is dominated by shelf-wide algal carbonate production, and has a coastal and an offshore siliciclastic sand supply, all within a high-energy setting. The inner ramp is characterized by laterally migrating sediment bedforms, areas of patch reefs and lithified Quaternary lithologies. The combination of high-frequency Quaternary sea-level changes together with the high-energy setting means that accumulation rates are very low and there is a close juxtaposition of highstand bioclastic carbonate sediments and lowstand siliciclastic sediments. These environmental and geological controls result in unusually complex relations between facies and depositional sequences, which serve as a model for the interpretation of ancient, ocean-facing, high-energy, inter-tropical ramp successions that have experienced high-frequency sea-level fluctuations.

\section{Methods of study}

This survey is based on the analysis of LandsatTM images, which are processed to illustrate the main differences between sea-floor structures and sea-bed composition. These are revealed by their different spectral signatures of reflected radiance recorded as different grey levels in satellite images (see Solewics 1989; Vianna et al. 1991; Testa 1996; Testa \& Bosence in press). The coordinates of the sampling sites were obtained using a geographical information system (GIS), and located in the field using a global positioning system (GPS). The images were groundtruthed by diving (120 sites; Fig. 3) and sea-floor observation and sampling. A total of five transects across the shallow shelf were investigated, with a maximum distance of $31 \mathrm{~km}$ from the shoreline and $27 \mathrm{~m}$ water depth (Fig. 3). Samples were analysed by standard sieving for textural data and point-counting for grain composition data (Testa 1996). ${ }^{14} \mathrm{C}$ dates were obtained on bulk samples of cemented lithologies that were obtained by hammer and chisel or underwater drill, and cleaned of all infauna and epifauna and present-day sediments. The samples were pretreated with controlled acid leaching $(0.5 \mathrm{M} \mathrm{HCl}$ at $20^{\circ} \mathrm{C}$ ) and dated at the NERC Radiocarbon Laboratory, East Kilbride. No corrections have been applied to the dates.

\section{Sedimentary zones and sediment transport on inner ramp}

\section{Shelf zonation}

The sediments and lithified Quaternary sandstones and limestones of the region occur in six zones whose orientation and occurrence reflect the high-energy setting of the shelf and its Quaternary history. These zones are distinct and mappable from satellite images as a series of belts of carbonate and siliciclastic deposits more or less parallel to the coast and shelf margin (Testa 1996; Testa \& Bosence in press) (Figs 3 and 4, Table 1).

The Coastal Zone $(\mathrm{CZ})$ comprises subaerial

Table 1. Summary of main sedimentary features characteristic of the zones on NE Brazilian ramp

\begin{tabular}{|c|c|c|c|c|}
\hline Setting & $\begin{array}{l}\text { Large-scale } \\
\text { feature }\end{array}$ & $\begin{array}{l}\text { Sediment } \\
\text { composition }\end{array}$ & $\begin{array}{l}\text { Sediment } \\
\text { texture }\end{array}$ & $\begin{array}{l}\text { Carbonate } \\
\text { percentage }\end{array}$ \\
\hline Coastal Zone (CZ) & scattered outcrops & siliciclastic & medium sand & $<6$ \\
\hline $\begin{array}{l}\text { Sublittoral Turbid Zone } \\
\text { (STZ) }\end{array}$ & $\begin{array}{l}\text { coral patch reefs, } \\
\text { buried reefs }\end{array}$ & $\begin{array}{l}\text { bioclastic } \\
\text { carbonate }\end{array}$ & $\begin{array}{l}\text { coarse sand- } \\
\text { gravelly sand }\end{array}$ & $>90$ \\
\hline $\begin{array}{l}\text { Sand Ribbon Zone } \\
\text { (SRZ) }\end{array}$ & sand ribbons & $\begin{array}{l}\text { bioclastic } \\
\text { carbonate }\end{array}$ & $\begin{array}{l}\text { coarse sand- } \\
\text { gravelly sand }\end{array}$ & 30 to $>90$ \\
\hline \multirow[t]{2}{*}{$\begin{array}{l}\text { Subaqueous Dune Zone } \\
\text { (SDZ) }\end{array}$} & very large dunes & $\begin{array}{l}\text { siliciclastic and } \\
\text { bioclastic } \\
\text { carbonate }\end{array}$ & $\begin{array}{l}\text { medium sand } \\
\text { coarse sand- } \\
\text { gravelly sand }\end{array}$ & 6 to $>90$ \\
\hline & sand plains & siliciclastic & medium sand & $<6$ \\
\hline $\begin{array}{l}\text { Algal Stabilized Zone } \\
\text { (ASZ) }\end{array}$ & $\begin{array}{l}\text { bed of branching } \\
\text { coralline algae }\end{array}$ & $\begin{array}{l}\text { bioclastic } \\
\text { carbonate }\end{array}$ & $\begin{array}{l}\text { coarse sand-- } \\
\text { gravelly sand }\end{array}$ & 60 to $>90$ \\
\hline $\begin{array}{l}\text { Lithified Sediment Zone } \\
\text { (LSZ) }\end{array}$ & $\begin{array}{l}\text { submerged } \\
\text { sandstone outcrop }\end{array}$ & $\begin{array}{l}\text { bioclastic } \\
\text { carbonate and } \\
\text { siliciclastic }\end{array}$ & $\begin{array}{l}\text { coarse sand- } \\
\text { gravelly sand }\end{array}$ & $>80$ \\
\hline
\end{tabular}




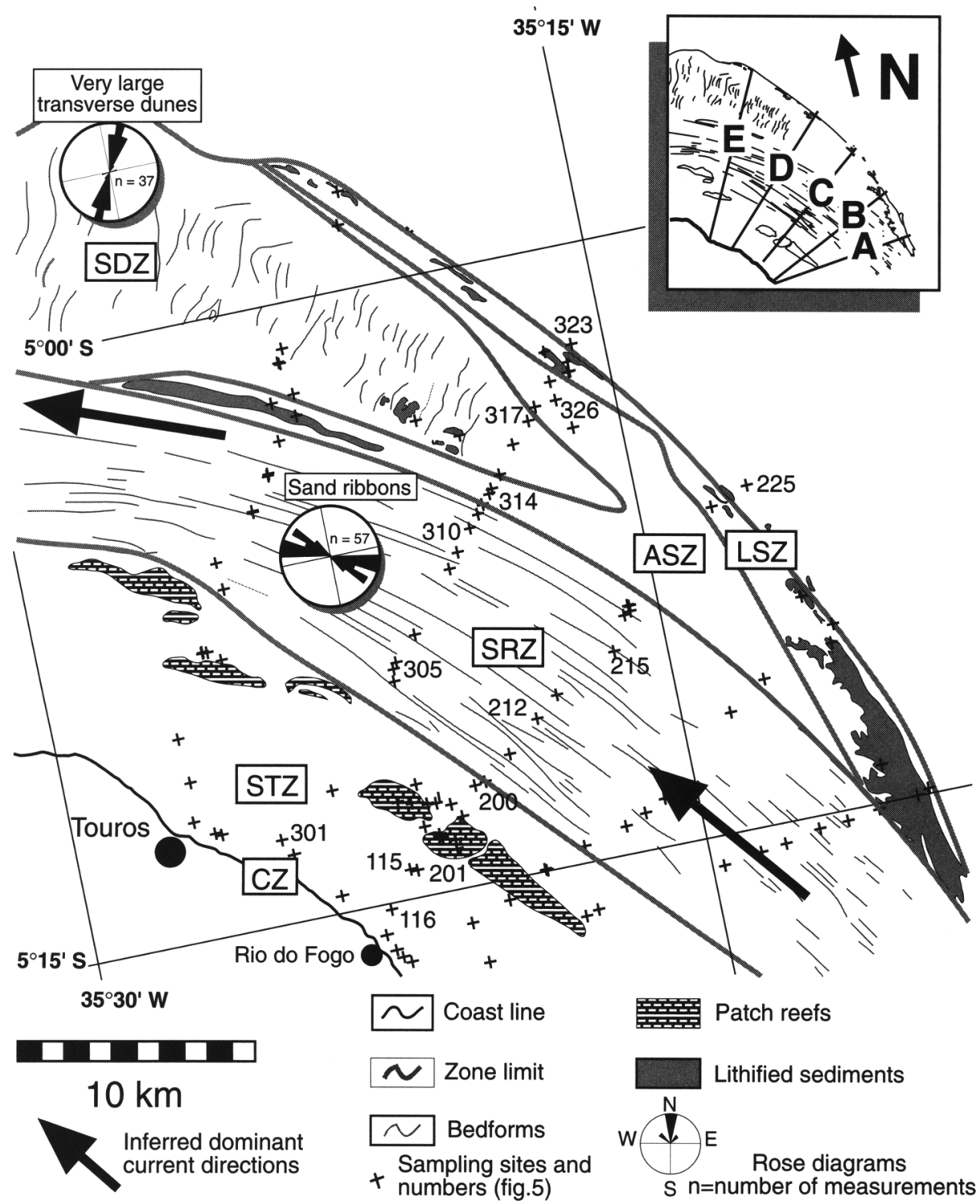

Fig. 3. Sedimentary zonation mapped from Landsat-TM image together with large-scale bedforms, sea-floor outcrops and reefs. Location of the sampling sites and five transects (A-E in inset) across the inner ramp, northeast Rio Grande do Norte State. Rose diagrams show the crest orientation of large-scale bedforms. CZ, Coastal Zone; STZ, Sublittoral Turbid Zone; SRZ, Sand Ribbon Zone; ASZ, Algal Stabilized Zone; LSZ, Lithified Sediment Zone; SDZ, Sand Dune Zone.

dunes and beaches of medium-grained quartz sand, with a minor carbonate content $(<6 \%)$. This comes from present-day bioclastic debris together with a contribution from erosion of low $(<4 \mathrm{~m})$ cliffs of a marine bioclastic grainstone dated as $>30 \mathrm{ka}$ BP (Testa et al. 1997). These rest unconformably on outcrops of the Pliocene
Barreiras Group (Srivastava \& Corsino 1984) and are interpreted to have formed in a Pleistocene highstand period. The Coastal Zone contrasts with the proximal Sublittoral Turbid Zone (STZ), where present-day coralline algal and Halimeda-rich sands are mixed with siliciclastic sands over a relatively narrow band below the 


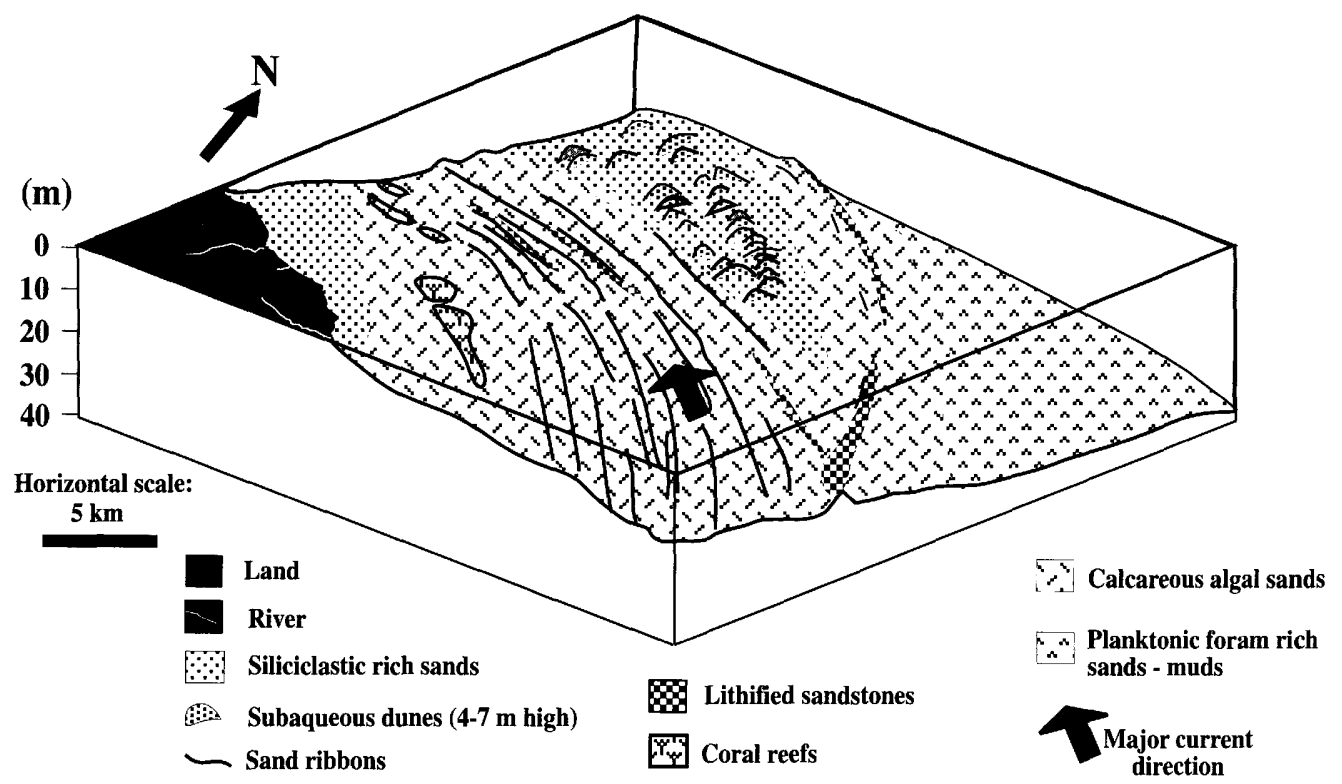

Fig. 4. Schematic block diagram of main depositional environments of inner to mid-ramp based on Landsat imagary and ground truthing along transects.

surf zone. The STZ is characterized by the occurrence of modern and sub-fossil (1000-1400 a BP) patch reefs located a few kilometres offshore (Fig. 3). The reefs are mainly built by Siderastrea and Millepora in association with crusts of crustose coralline algae (Lithophyllum and Mesophyllum) (Testa 1997). The sub-fossil reefs are truncated, most probably because of erosion that occurred during a local sea-level lowstand during late Holocene time, and today are being gradually buried by carbonate sand (Testa 1997).

Between the coast and the patch reefs waverippled Halimeda-rich sands and seagrass beds are found. Offshore from the reefs are areas of abraded and reworked rhodoliths. These are generally colonized by fleshy brown or red algae.

Offshore from the STZ is the Sand Ribbon Zone (SRZ), which is characterized by large, coast-parallel sand ribbons that are tens of kilometres in length and hundreds of metres across (Figs 3 and 4) (Testa \& Bosence in press). Both sand ribbon crests and troughs are composed of bioclastic sands and gravels. The crests are composed of coralline algal rich sand, whose tops are reworked by small wave-generated dunes. The troughs are characterized by the development of coralline algal maërl (branching, free-living coralline algae) and rhodolith communities (Testa 1996; Testa \& Bosence in press).
The Algal Stabilized Zone (ASZ) is the next zone offshore and partially encloses the Subaqueous Dune Zone (SDZ) (Figs 3 and 4). The former is characterized by a stabilized bed of branching coralline algae, Halimeda gracilis and other, noncalcified, seaweeds. The SDZ is defined by the occurrence of very large, transverse dunes (for details, see Testa \& Bosence (in press)). The subaqueous dunes are composed of siliciclastic sands, but the interdune areas have accumulations of bioclastic sediments, meadows of Halimeda incrassata and rhodoliths or coralline algal maërl.

The Lithified Sediment Zone (LSZ) forms the edge of the inner ramp, and comprises large $(4 \mathrm{~km} \times 50 \mathrm{~km}$ and up to $4 \mathrm{~m}$ high) submerged outcrops of carbonate-cemented, horizontally bedded and laminated sandstones (Figs 3 and 4). These outcrops, in depths of $c .20 \mathrm{~m}$, show many features of sea-floor erosion in the form of undercutting and potholing, and are locally encrusted by coralline algae and sponges, and colonized by Halimeda and other fleshy algae. In thin section the sandstones are seen to be quartz rich, but with up to $20 \%$ Foraminifera, coralline algae and mollusc grains. They show phases of marine high-Mg calcite cementation, dissolution and low-Mg calcite cementation, which are interpreted to have occurred respectively in marine and in fresh water environments. The 
calcareous sandstones provide a bulk sample, minimum ${ }^{14} \mathrm{C}$ date of 5540 a $\mathrm{BP}$ and are interpreted to be a former Holocene lowstand beach-barrier shoreline (Testa et al. 1997). The age is regarded as a minimum because of the diagenetic alteration of the marine bioclasts. The sands within these outcrops are petrograpically identical to those of the SDZ occurring downstream of these outcrops, and they are thought to have been a time-limited source for the dune sands. Little erosion occurs today in the LSZ and the sandstones are partially overgrown by thin coralline algal crusts. The sands are also petrographically similar to those of the present day Coastal Zone despite their separation by $30 \mathrm{~km}$.

\section{Sediment transport}

Analysis of Landsat images, and in situ measurements and observations of bedforms reveals that the sand ribbons and the transverse dunes in the inner ramp are active, and in equilibrium with the present-day hydrodynamic environment (for details, see Testa \& Bosence in press). The orientation of the sand ribbons and the submarine dunes (Fig. 3) indicates that coast-parallel currents are of prime importance in the reworking and transportation of sediments along the inner ramp (Testa \& Bosence in press). However, the occurrence of symmetric wave ripples $(70-120$ $\mathrm{cm}$ spacing) with crests also orientated parallel to the coast, on the sand ribbons and on the large transverse dunes, indicates that there is also a shoreward flow of a smaller magnitude. This flow is interpreted to be a combination of waves and tides, and is responsible for the transport of sediments from offshore areas of carbonate production to shallower, more siliciclastic-rich inshore areas (Testa \& Bosence in press). It may also explain why the patch reefs are undergoing burial by carbonate sediments in most of the investigated reef areas (Testa 1997). The bedforms within the area therefore indicate a complex interplay of currents, tides and waves as processes influencing sediment transport in the inner ramp environment (Fig. 2).

\section{Texture, composition and origin of sediments}

Carbonate sediments. Despite the occurrence of different sedimentary zones the texture and composition of the carbonate sediments do not vary significantly across the inner ramp (Fig. 5). Areas of high carbonate production (troughs of sand ribbons, some interdune areas and most of the ASZ) are composed of coarse sand to gravelly sand, related to the prolific growth of branching coralline algae. The only area with finer-grained sediments is the inshore area of transect C (Fig. 5) in the STZ inshore of the patch reefs, suggesting some degree of shelter from the more exposed offshore areas. The in situ development of rhodoliths produces a consistently coarser size fraction varying from -3 to $-6 \phi$ (Fig. 5). The coralline algae commonly form up to $50 \%$ of the sands and their abundance is only reduced when siliciclastic grains increase in abundance. Articulated (or geniculate) coralline algal branch fragment were separately counted and these appear to be more abundant in the shallower-water sites. This probably reflects the abundance of the living plants (mainly Amphiroa) on hard substrate areas (e.g. patch reefs in Transect C, Fig. 5) within the area. Halimeda and molluscs are also common but variable contributors of granule- to sand-sized material to the sediments. It should be noted that coral fragments are rare, despite the coral patch reefs in the inshore region.

Because of the lack of variability in the abundance of the carbonate grains and the dominance by the ubiquitous calcareous algae, there does not appear to be any one locus of carbonate production within the inner ramp area investigated.

Siliciclastic sediments. Quartz sands produce the main variations in grain abundance and are mainly found along the coast and in the SDZ (Fig. 5). These sands are finer grained than the surrounding carbonate sediments and their presence affects the abundance of all other carbonate grains. Siliciclastic pebbles have a localized contribution in offshore areas approximately at the level of the $15 \mathrm{~m}$ isobath and near the LSZ. Their localized occurrence and large grain size suggest these are reworked earlier deposits and are not related to the present-day terrigenous input.

There are clearly two main sources and accumulation sites for siliciclastic grains within the area. Coastal regions have a strip of quartzrich sands that are recycled by coast-parallel transport in subaerial dunes and on beaches; there is little evidence for significant onshore-offshore transport of this sand. The offshore transverse dune field of siliciclastic sand is largely isolated from the coastal sand (Figs 2 and 5). Transport pathways (Fig. 3) and the petrographic similarity of the grains indicate that the likely source for this sand is from previous erosion of the quartz sandstones of the LSZ. This supply of sand has now been cut off as the sandstones are being encrusted by coralline algae and other epibionts, and a thin, patchy 
a)
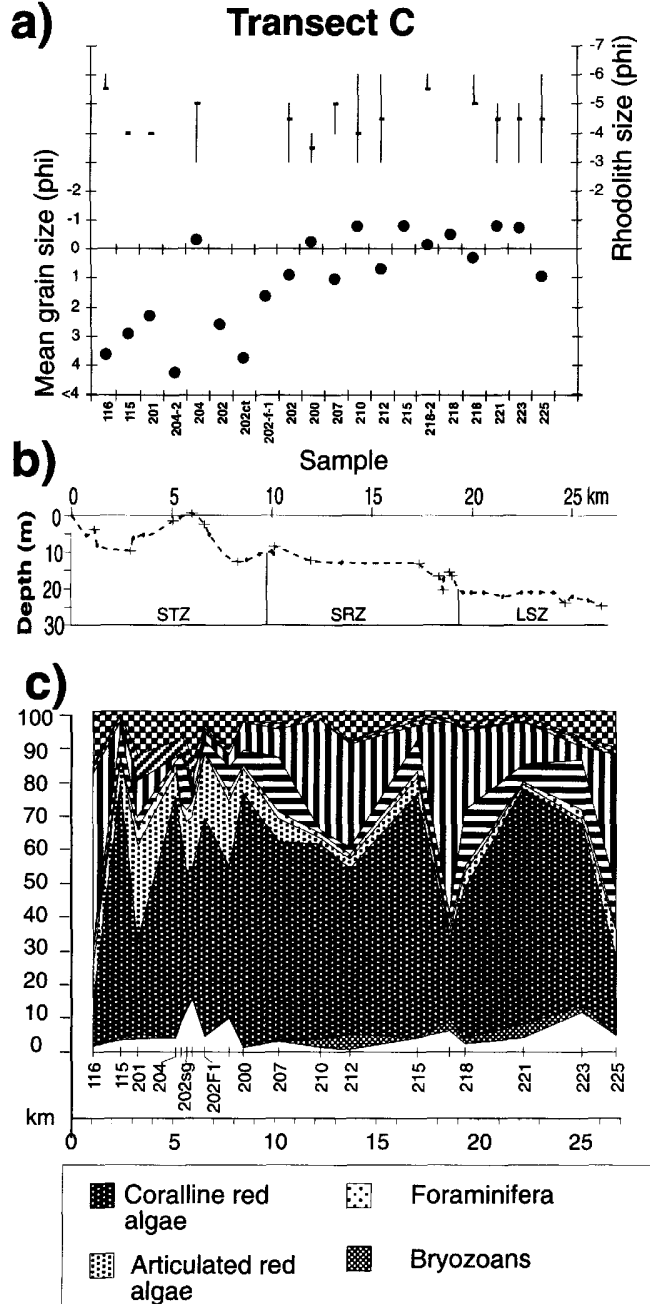
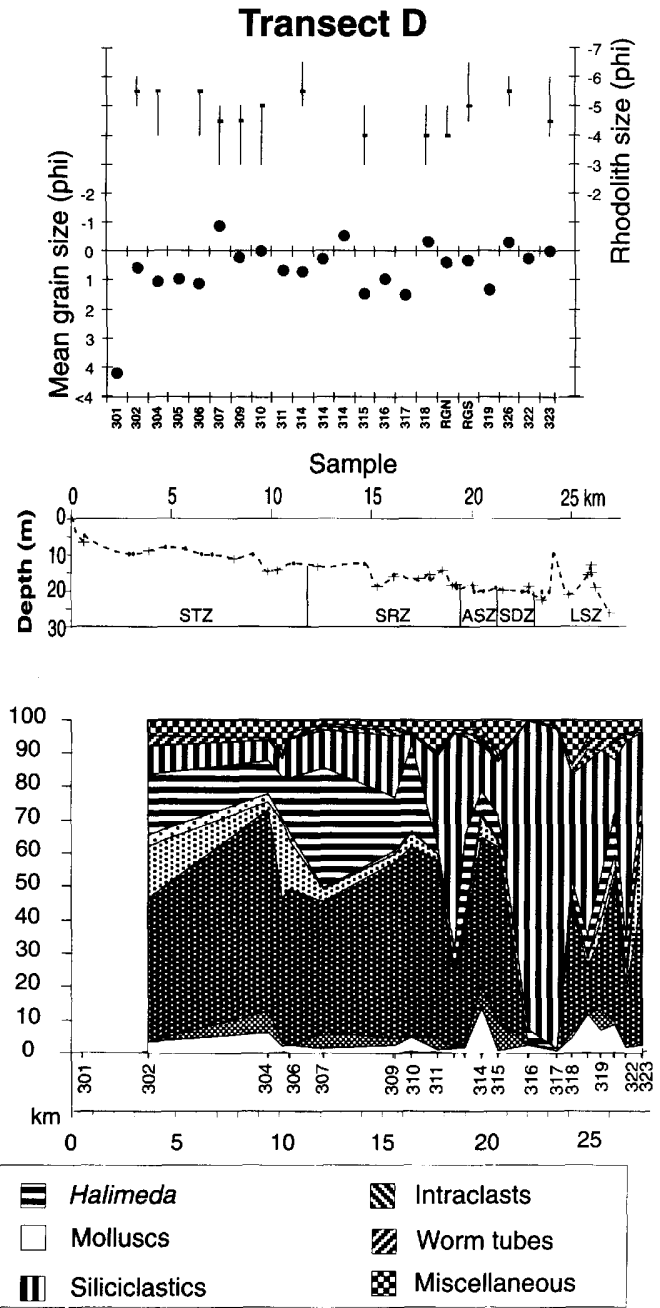

Fig. 5. Compositional variation along Transects C and D (Fig. 3) showing (a) grain-size variation of sediments and rhodolith fraction, (b) depth profiles along transects, and (c) abundance of grain types based on point counts of bulk sediment.

layer of mainly bioclastic sediments (Fig. 4) accumulates around these submarine outcrops today. The dune field today is therefore isolated from its source, and is surrounded by presentday carbonate production and accumulation.

\section{Carbonate-siliciclastic mixing in the inner ramp environment}

Environments characterized by both carbonate and siliciclastic sediments are common on modern and ancient continental shelves. Different mixing processes occur that are dependent on shelf morphology, hydrodynamic energy, the nature and abundance of carbonate-producing organisms, the nature and rate of siliciclastic supply and the geological history of the area (Mount 1984). Frequently, there is a delicate balance between carbonate and siliciclastic grain supply so that carbonate and siliciclastic facies are closely juxtaposed in ancient sequences. Within the inner ramp of Northeast Brazil carbonate-siliciclastic mixing occurs through a number of different processes that are detailed below. However, many of the carbonate-siliciclastic relations on this Brazilian ramp have an underlying historical control 
that is ultimately related to sediment supply and the high-frequency sea-level changes in the region.

\section{Sediment supply on Northeast Brazilian ramp}

Carbonate sediment supply. The effects that sealevel change will have on carbonate facies depend largely on how carbonate-producing organisms cope with sea-level oscillations (Nelson et al. 1982), temperature and salinity fluctuations (Lees 1975), or sediment transport (Wilson 1979, 1986, 1988). Most of the carbonate production on the Northeast Brazil ramp is by the prolific development of calcareous algae rather than by corals. Evidence from the Sand Ribbon and Subaqueous Dune Zones indicates that coralline algae and rhodoliths can be easily transported, without significant damage, by moderate to strong currents. Similarly, Halimeda is able to colonize various loose sediment or cemented substrata (Testa 1997). This suggests that calcareous algae may be better able to cope with rapid sea-level oscillations in a moderate- to high-energy setting than would corals, which require a stable, rather than a mobile substrate. This may explain the abundance of calcareous algae within an area of clear open-ocean, inter-tropical waters that might otherwise be expected to be dominated by corals (see Lees 1975). One important effect of the dominance by calcareous algae is that algal grains are produced ubiquitously throughout the inner ramp environment. There is no locus of carbonate sediment production as is found on coral-dominated carbonate platforms.

Siliciclastic sediment supply. The Northeast Brazil ramp is also unusual in that it has two separate sources of siliciclastic sand whose distributions are related to Quaternary sea-level changes. The sands are thought to have been derived originally from the underlying quartzrich Barreiras Formation. Today sand is found in the outer part of the inner ramp, where the earlier, $>5540$ a BP, siliciclastic shoreline sands have been eroded to form an isolated, and timelimited, sand supply. This is considered to have been the source of the present-day subaqueous dune field. Carbonate producers have colonized, but not yet buried, the submerged outcrops of sandstones in the subsequent Holocene highstands. Also, a present-day sand belt, slightly oblique to the present-day coast, is being transported to the northwest by coastal processes within the beach-dune system. Therefore siliciclastic sands are being reworked and transported parallel to the coast in two separate coastal and sublittoral zones.

\section{Processes of carbonate-siliciclastic mixing}

Mount (1984) recognized four processes associated with the mixing of carbonate and siliciclastic deposits: punctuated mixing, facies mixing, in situ mixing and source rock mixing (Table 2). Punctuated mixing involves transfer of sediments during rare high energy events such as storms; facies mixing occurs along the diffuse borders between contrasting facies; in situ mixing occurs through the autochthonous carbonate production within a siliciclastic sediment; source rock mixing occurs when carbonate or siliciclastic material is eroded and supplied to a contrasting facies. All these processes occur in Northeast Brazil, and details of the mixing agents, the facies and the texture of the mixed sediments are given in Table 2 .

The various types of mixing are not exclusive to individual zones and any one zone may have more than one type of mixing process. The relative importance of the different mixing processes varies according to the environment investigated. The carbonate grains of the $\mathrm{CZ}$ derive from two sources (Fig. 6): stained carbonate grains are eroded from the Pleistocene bioclastic grainstone cliffs (source rock mixing), and living or dead rhodoliths and their fragments are brought in by waves and by spring tides (facies mixing). In the STZ, facies mixing also occurs as a result of the adjacent transport of siliciclastic material from the coast and from the longshore and onshore transport of carbonate clasts.

The type of carbonate-siliciclastic mixture that most clearly characterizes the modern sediments of the area is in situ mixing. This occurs where later Holocene highstand carbonate production generates bioclasts on and within the earlier siliciclastic sediments. The trough areas of the SDZ and the bioclastic sands around the LSZ represent examples of this (Fig. 6).

A narrow belt in the SRZ, at c. $15 \mathrm{~m}$ water depth and about $15 \mathrm{~km}$ offshore, comprises coarse bioclastic carbonates in association with bimodal coarse- and fine-grained siliciclastic sand. This mixed sediment is interpreted as a former siliciclastic deposit that is unconnected to any siliciclastic supply today. It may relate to the maximum offshore extent of the siliciclastic Barreiras Formation, which today outcrops locally along the coast. The absence of a supply of siliciclastic sediments to this area today and the prolific calcareous green and red algal growth in 


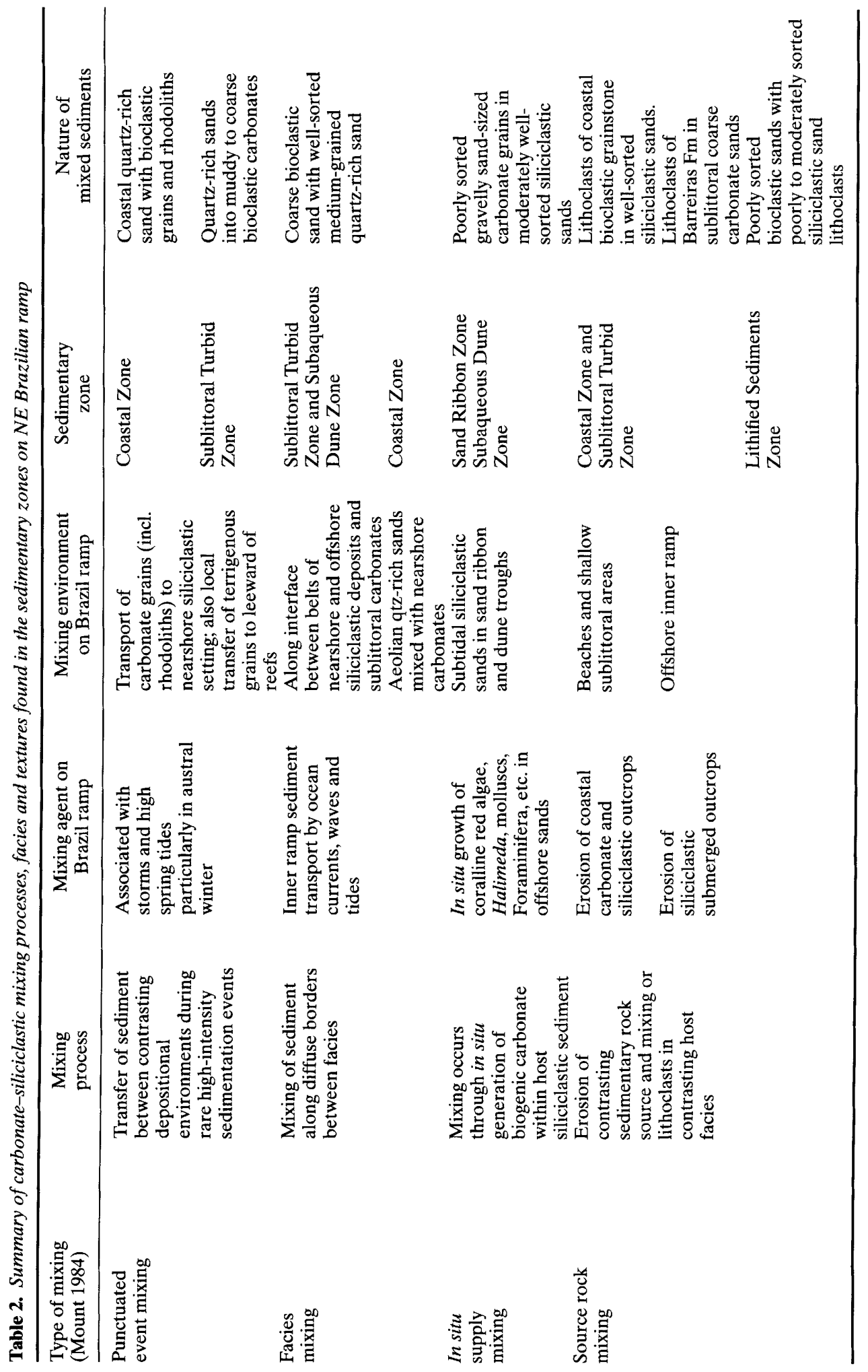


를를

宏岂㕈

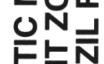

是色产

它品

을

क乞至

山ய山

뚠은

음

宛

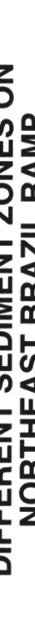

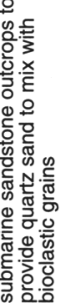
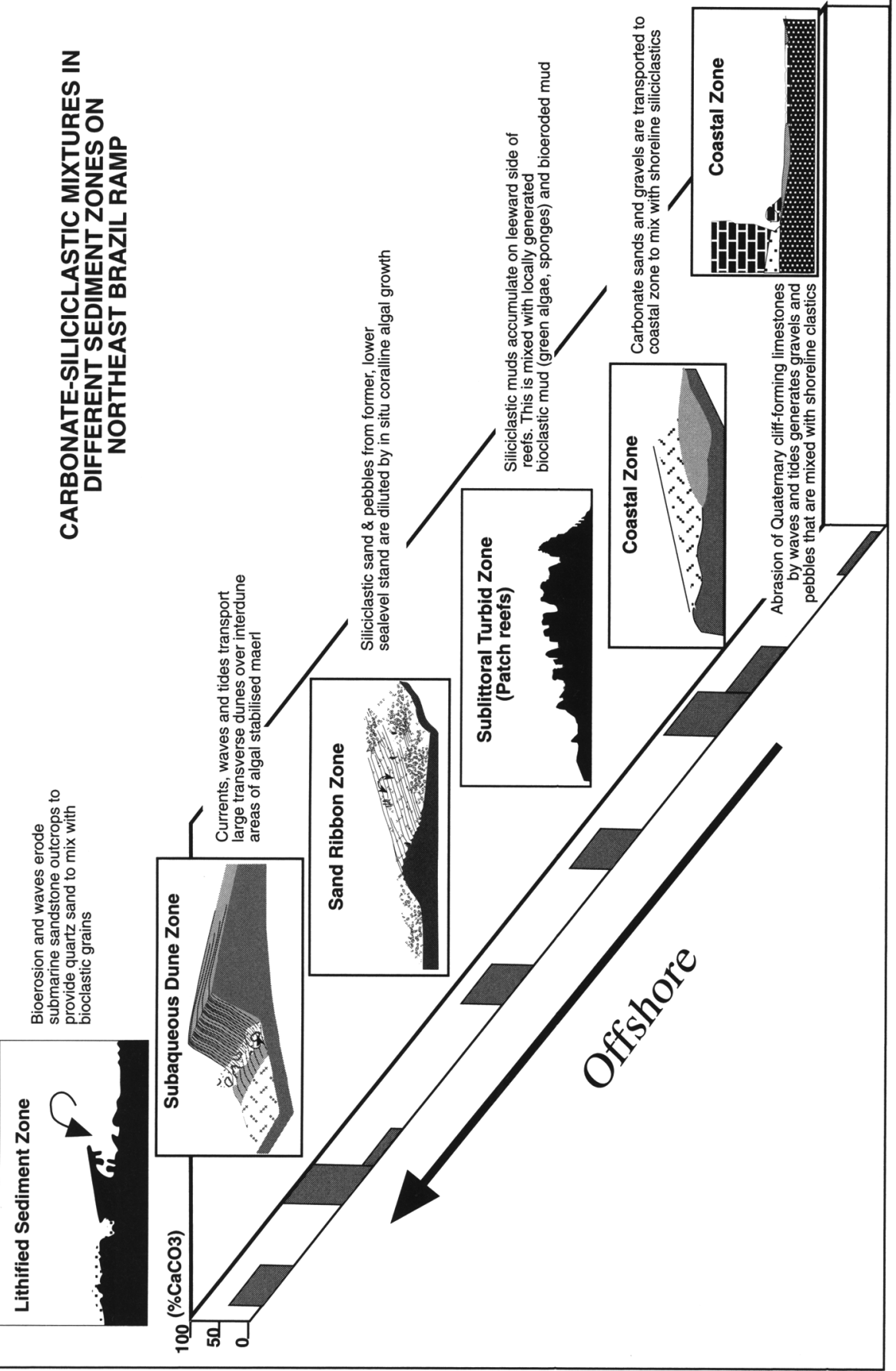

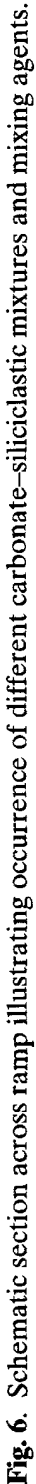


the area will eventually transform and bury this earlier siliciclastic deposit.

Mixing of carbonate and siliciclastic deposits is likely to be favoured in a high-energy ramp system, where the low-angle shelf profile and the high hydrodynamic energy facilitate sediment transport in a variety of directions and with fewer restrictions than those found on rimmed shelves. In addition, sea-level oscillations on a gently sloping ramp will repeatedly mix shoreline-derived clastic sediments, which are shifted further down ramp during relative sea-level lowstands, whereas shallow-marine carbonates will dominate in relative highstands. Depending on the rate of sediment accumulation, these different grain assemblages may be vertically separated as discrete stratigraphic packages when accumulation rates are high, or will be intermixed, as on the Northeast Brazilian ramp, when accumulation rates are low.

\section{Comparisons with Recent distally steepened tropical ramps from Yucatan and west Florida}

We are not aware of any other inter-tropical carbonate ramps that have similar high-energy, calcareous algal facies that interdigitate with clastic sediments and are affected by such highfrequency relative sea-level changes. The Northeast Brazilian example may, therefore, be unique because of its environmental and geological setting. However, there are two wellstudied examples of distally steepened ramps from the inter-tropical region of the west Atlantic: the western Florida shelf (Fig. 7a) (Doyle \& Sparks 1980; Mullins et al. 1988) and the Yucatan Peninsula (Fig. 7b) (Logan et al. 1969) which serve as useful comparisons (Table 3 ) that illustrate some of the broader controls on the sedimentology of tropical ramps.

\section{Morphological and oceanographic setting}

These three margins are similar in that they are all attached, distally steepened ramps, on lowrelief continental margins facing into the Atlantic Ocean or the Gulf of Mexico. The Brazilian ramp is considerably narrower than the Yucatan and the west Florida ramps (Table 3), and the steep ramp slope is fault related and inherited from the Mesozoic Atlantic rifting. The west Florida ramp is distally steepened through the large-scale collapse of the outer ramp slope along listric faults related to the steeply sloping west Florida Escarpment (Mullins et al. 1988).
The Yucatan ramp is a drowned Cretaceous to Tertiary flat-topped shelf.

The ramps show similarities in that the dominant current on each of the three ramps is parallel to shore and ramp margin, the currents on all three ramps being generically linked to the easterly to northeasterly flowing South Equatorial Current (SEC) (Fig. 1). The North Brazil Current (NBC), plus tides and winds-waves, is predominantly following the coast and ramp margin as it swings from a northerly flowing current in the east to a northwesterly flowing current in the west. The Yucatan ramp is affected by the Yucatan Current (a derivative of the NBC), which follows the contours westwards around the Yucatan Peninsula and is responsible for low-velocity currents $(c .1 .5 \mathrm{~cm} / \mathrm{s}$ ) sweeping gently across the shelf (Logan et al. 1969). The northern part of the ramp is oriented to face the winter northerly and northeasterly winds and waves, but the western part of the ramp is parallel to these currents. The Loop Current of the western Gulf of Mexico derives from the Yucatan Current and sweeps along the western Florida ramp with surface velocities up to 200 $\mathrm{cm} / \mathrm{s}$ but decreasing to $20-30 \mathrm{~cm} / \mathrm{s}$ at $500 \mathrm{~m}$ and $4 \mathrm{~cm} / \mathrm{s}$ at $1000 \mathrm{~m}$ (Mullins et al. 1988). Wind and wave currents are parallel to the coast, northerly in winter and southerly in the summer. Sediment transport in the inner to mid-ramp is therefore predominantly along the ramp in each of these cases.

\section{Siliciclastic supply}

The Northeast Brazil ramp is isolated from present-day clastic supply by the absence of any large inflowing rivers except to the west, where any clastic supply is transported to the west by the NBC. Quartz-rich sands derived from the Tertiary Barreiras Formation are redistributed over the inner ramp during lowstands and trapped in the shoreline, or stranded offshore during highstands. The Yucatan ramp is devoid of any significant clastic input because of the absence of large rivers and a carbonate hinterland, but the western Florida shelf has a quartzrich sand belt along the coast (less than $c .20 \mathrm{~m}$ depth), which is thought to be derived from erosion of Tertiary sands during periods of lower sea level (Doyle \& Sparks 1980). Finegrained clastic material in the outer slope is supplied today by easterly flowing Loop Current from the Mississippi delta region. The three ramps therefore differ in their clastic supply (Table 3), which reflects their different settings and geological histories. However, the shoreline siliciclastic deposits on the Brazilian and 


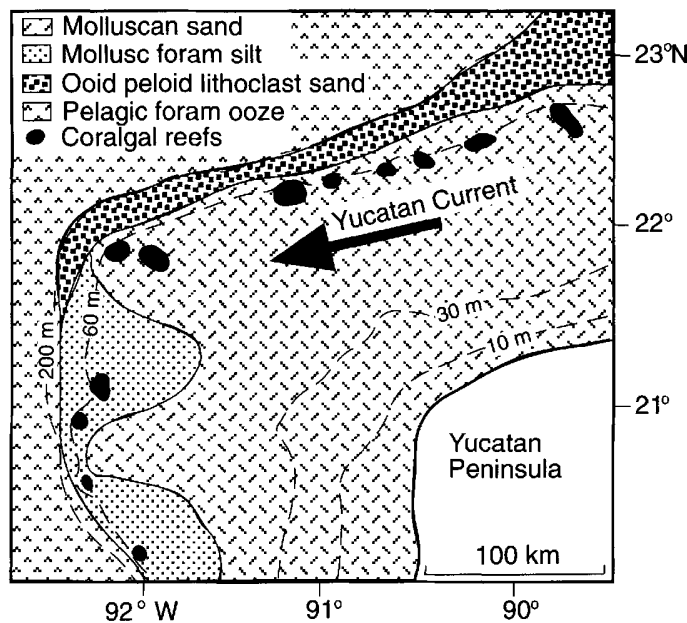

a)

Fig. 7. Summary maps showing morphology and facies of distally steepened, tropical ramps from (a) Yucatan (after Logan et al. 1969) and (b) west Florida (after Doyle \& Sparks 1980; Mullins et al. 1988). (For locations see Fig. 1.)

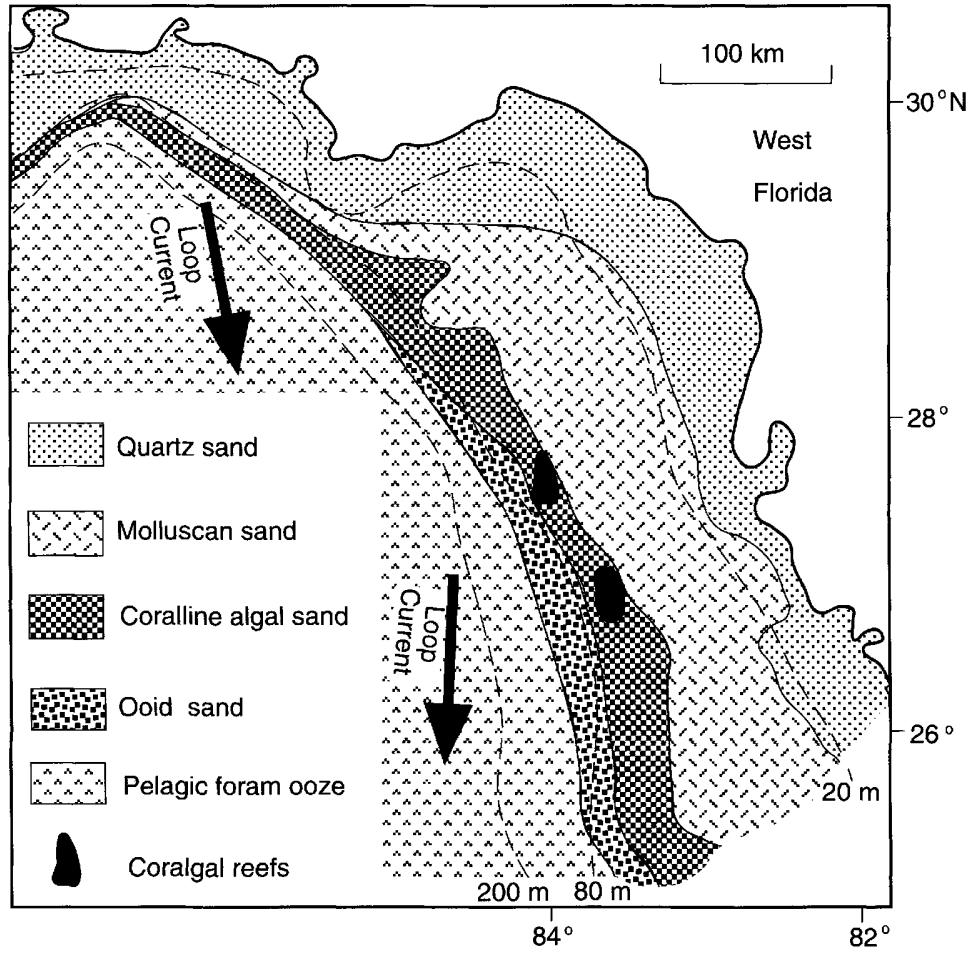

west Florida ramp appear to have a similar origin.

\section{Inner ramp carbonate facies}

With respect to the inner ramp area (taken in each case where medium- to coarse-grained, grain-supported textures or hard substrates occur) the Gulf of Mexico ramps differ from the Brazilian example in that they both have mollusc-rich sands down to 50-60 m depth whereas calcareous algal sands and gravelly sands dominate in Brazil. Out of the three ramps the Brazilian example has the largest area of coral patch reefs; small, inshore coral-rich areas are found in west Florida. The equivalent 
Table 3. Comparison of features of tropical, distally steepened ramps from Brazil (this work), Yucatan (Logan et al. (1969) and west Florida (Doyle \& Sparks 1980; Mullins et al. 1988)

\begin{tabular}{|c|c|c|c|}
\hline & Northeast Brazil & Yucatan & West Florida \\
\hline Morphology & $\begin{array}{l}\text { Distally steepened } \\
\text { ramp }\end{array}$ & $\begin{array}{l}\text { Distally steepened } \\
\text { ramp }\end{array}$ & $\begin{array}{l}\text { Distally steepened } \\
\text { ramp }\end{array}$ \\
\hline Width & $80 \mathrm{~km}$ to $200 \mathrm{~m}$ isobath & $\begin{array}{l}200-250 \mathrm{~km} \text { to } \\
200 \mathrm{~m} \text { isobath }\end{array}$ & $\begin{array}{l}100-200 \mathrm{~km} \text { to } \\
200 \mathrm{~m} \text { isobath }\end{array}$ \\
\hline Climate & $\begin{array}{l}\text { Seasonal arid to humid } \\
\text { equatorial }\end{array}$ & Humid tropical & Humid subtropical \\
\hline $\begin{array}{l}\text { Dominant current } \\
\text { and sediment } \\
\text { transport direction }\end{array}$ & $\begin{array}{l}\text { Parallel to coast and } \\
\text { ramp margin; } \\
\text { transport to northwest }\end{array}$ & $\begin{array}{l}\text { Parallel to coast and } \\
\text { ramp margin; } \\
\text { some transport to west }\end{array}$ & $\begin{array}{l}\text { Parallel to coast and } \\
\text { ramp margin; } \\
\text { inner ramp transport to } \\
\text { north (summer) and to } \\
\text { south in (winter); } \\
\text { ramp slope transport to } \\
\text { south }\end{array}$ \\
\hline $\begin{array}{l}\text { Wind-wave } \\
\text { exposure }\end{array}$ & $\begin{array}{l}\text { Windward facing ramp; } \\
\text { southeasterly winds; } \\
\text { high energy }\end{array}$ & $\begin{array}{l}\text { Windward to leeward } \\
\text { facing ramp; } \\
\text { northeasterly to } \\
\text { southeasterly winds; } \\
\text { moderate energy }\end{array}$ & $\begin{array}{l}\text { Ramp is parallel to } \\
\text { northerly (winter) and } \\
\text { southerly (summer) } \\
\text { winds; moderate energy }\end{array}$ \\
\hline $\begin{array}{l}\text { Siliciclastic } \\
\text { supply }\end{array}$ & $\begin{array}{l}\text { Inner ramp reworked } \\
\text { quartz-rich sand }\end{array}$ & Negligible & $\begin{array}{l}\text { Quartz-rich sand } \\
\text { reworked in inner ramp; } \\
\text { mud from northwest } \\
\text { carried along outer ramp } \\
\text { slope }\end{array}$ \\
\hline $\begin{array}{l}\text { Inner ramp } \\
\text { carbonate facies }\end{array}$ & $\begin{array}{l}\text { Calcareous algal sand } \\
\text { with rhodoliths with } \\
\text { large-scale dunes and } \\
\text { sand ribbons; coralgal } \\
\text { patch reefs }\end{array}$ & $\begin{array}{l}\text { Molluscan, intraclastic } \\
\text { sands }\end{array}$ & Molluscan, quartz sands \\
\hline $\begin{array}{l}\text { Mid-outer ramp } \\
\text { slope facies }\end{array}$ & $\begin{array}{l}\text { Planktonic foram sands } \\
\text { with increasing mud } \\
\text { content with depth }\end{array}$ & $\begin{array}{l}\text { Relict coralgal reefs on } \\
60-70 \mathrm{~m} \text { terrace with } \\
\text { ooid, peloid lithoclast } \\
\text { sands plus modern } \\
\text { planktonic foram sands }\end{array}$ & $\begin{array}{l}\text { Relict hardgrounds and } \\
\text { coralline algal and ooid } \\
\text { limestones } 200-400 \mathrm{~m} \text {; } \\
\text { winnowed planktonic } \\
\text { foram sands } 400-600 \mathrm{~m}\end{array}$ \\
\hline Outer ramp facies & $\begin{array}{l}\text { Planktonic foram ooze } \\
>100-150 \mathrm{~m}\end{array}$ & $\begin{array}{l}\text { Planktonic foram ooze } \\
>60-200 \mathrm{~m}\end{array}$ & $\begin{array}{l}\text { Planktonic foram ooze } \\
>600 \mathrm{~m}\end{array}$ \\
\hline
\end{tabular}

structures on the Yucatan shelf are drowned reefal build-ups at $c .60 \mathrm{~m}$ depth, reflecting its history of undiluted carbonate sedimentation on the ramp.

This major difference in the inner ramp facies is interpreted to relate to the different levels of hydrodynamic energy within the three ramps. The Brazil shelf is narrow, and faces the openocean winds, waves and the SEC; the inner ramp sediments are actively transported by highenergy, large-scale bedforms. Coralline algae are seen to thrive in these conditions and are seen to sometimes stabilize the sea floor (e.g. ASZ and inter-dune and inter-sand ribbon troughs) and even modify some of the largescale bedforms (Testa \& Bosence in press).
Although some molluscs can exist in these highenergy settings, they never dominate, and molluscan grains rarely exceed $10 \%$ abundance in Northeast Brazil (Fig. 4). Similarly, shallow coralgal patch reefs are more abundant on the Brazilian ramp, which faces the open ocean, than the more protected Yucatan and west Florida ramps.

\section{Mid- to outer ramp slope}

All three examples have topographic or lithological units related to former Holocene lowstands, but in each case they are different, reflecting the different environmental settings and geological histories of the ramps. In Brazil 
the main lowstand feature that has been identified to date is the LSZ at $c .20 \mathrm{~m}$ depth but it has not been precisely dated. However, its location and extent, its sediment structures and textures, and a minimum ${ }^{14} \mathrm{C}$ age of 5540 a $\mathrm{BP}$ all suggest that it relates to a Holocene lowstand period. The Yucatan ramp differs because of its pure carbonate setting, and here the lowstand deposits are coralgal reefs in $50-60 \mathrm{~m}$ water depth surrounded inshore by molluscan and lithoclast sands, and offshore by relict $\left({ }^{14} \mathrm{C}\right.$ ages 13.32-10.93 ka BP) ooid, peloid and lithoclast sands mixed, by burrowing, with modern planktonic Foraminifera (Logan et al. 1969).

Although specific lowstand features have not been described from the west Florida shelf, a number of cemented Quaternary lithologies occur (planktonic foraminiferal grainstone, Lophelia coral framestone and rhodolith rudstone) that have a maximum ${ }^{14} \mathrm{C}$ age of $c .15 \mathrm{ka}$ BP (Mullins et al. 1988). Mullins et al. showed that the outer shelf is characterized by hardgrounds with rhodolith rudstones between $c$. 200 and 400 $\mathrm{m}$. Between $c$. 400 and 600 a winnowed planktonic foraminiferal sand occurs, and a bioturbated planktonic foraminiferal ooze occurs beyond $c .600 \mathrm{~m}$. This relatively high-energy mid-outer ramp setting in west Florida relates to the contour-hugging Loop Current, which is clearly effective in transporting sediment down to $c$. $600 \mathrm{~m}$ water depth. This current is thought to have been strengthened on this margin in mid-Miocene time, when the Isthmus of Panama was formed, which intensified the Loop Current-Gulf Stream circulation in the area (Mullins et al. 1988).

\section{Outer ramp facies}

The outer ramp deeper-water facies in all three cases are similar planktonic Foraminifera oozes suggesting similar, relatively quiet-water setting at depths $>80 \mathrm{~m}$ (Northeast Brazil), 50-200 m (Yucatan) and $>600 \mathrm{~m}$ (west Florida). The greater depth at which this facies occurs in Florida is due to the depth at which the Loop Current impinges on the outer slope (Mullins $e t$ al. 1988).

\section{Conclusions}

\section{Geological and environmental setting}

Because of its geological history and environmental setting the Brazilian ramp shows a number of unusual features. The distally steepened ramp inherits its profile from Atlantic margin rifting and results in a narrow $(50 \mathrm{~km})$ inner to mid-ramp zone. Underlying Tertiary sandstones provide a local source for quartz-rich sands that are reworked within the Quaternary carbonate sediments. The narrow ramp profile faces the full force of the South Equatorial Current and westerly winds, resulting in a highenergy open-ocean equatorial setting in a high meso-tidal regime.

\section{Sedimentary zones and sediment transport}

The sedimentary zones from the inner ramp are characterized by subaerial dunes, beaches, patch reefs, large-scale, high-energy sand ribbons and transverse dunes generated by currents flowing parallel to the coast and ramp slope. Quartz-rich sands occur in the shoreline and offshore from the erosion of sea-floor outcrops of sandstones to form an offshore, northwesterly moving dune field. Patch reefs occur in shallow areas and locally provide shelter for the only muddy sediments in the area. There are extensive areas of sea-floor cemented and stabilized coralline algal beds. All other areas accumulate a coarse coralline algal and Halimeda-rich sand with rhodoliths.

\section{Quaternary history}

The location, altitude, palaeoenvironment and preliminary ${ }^{14} \mathrm{C}$ dating of lithified units indicate three major phases in the Quaternary history of the shelf. A Pleistocene ( $>30 \mathrm{ka}$ BP) highstand period accumulated high-energy, inner ramp calcareous algal sands that today form $<4 \mathrm{~m}$ high coastal cliffs. A Holocene lowstand period ( $>5540$ a BP) drew quartz sands out over the inner ramp to form a beach-barrier complex that today lies at c. $20 \mathrm{~m}$ depth some $30-30 \mathrm{~km}$ offshore. The Holocene transgression and highstand has reworked earlier sediments, and today the area is dominated by calcareous algal sands and gravels.

\section{Carbonate-siliciclastic mixing}

High-frequency relative sea-level changes have resulted in a complex and close juxtaposition of Quaternary highstand carbonates and lowstand siliclastic facies that are being mixed in the present-day inner ramp environment. Carbonate-siliciclastic mixing occurs through (a) in situ growth of carbonate producing organisms in clastic sands, (b) erosion of lithified outcrops to provide limestone and sandstone intraclasts which accumulate in contrasting facies, and (c) various forms of sediment transport (waves, tides and oceanic currents) that mix historically adjacent carbonate and siliciclastic facies. 


\section{Comparisons with other tropical Atlantic ramps}

Comparison with tropical ramps from Yucatan and west Florida indicates that they are all distally steepened ramps with a slope ultimately inherited from Atlantic-Gulf of Mexico rifting. Because these ramps are swept by the powerful South Equatorial Current, or its derivative Yucatan and Loop Currents, the low-angle, inner ramp areas are all dominated by coast-parallel currents and sediment transport. Although the siliciclastic facies on each ramp differ because of the different natures of their siliciclastic supply, carbonate facies are similar in that they are all dominated by marine, bioclastic carbonates. However, the Brazilian inner ramp is dominated by calcareous algal sand, gravel and rhodoliths, and by patch reefs, whereas the Gulf of Mexico ramps are mainly molluscan sands. This is interpreted to be a hydrodynamic control favouring high-energy algal facies in Brazil. Outer ramp planktonic Foraminifera oozes occur at $>80 \mathrm{~m}$ in Brazil, $>50-200 \mathrm{~m}$ in Yucatan but at depths $>600 \mathrm{~m}$ in west Florida because of the influence of the Loop Current.

The present research was undertaken with a $\mathrm{CNPq}$ grant (260178/91.8) to V.T., with fieldwork funded by the Natural Environmental Research Council, UK (GR9/12660) and the radiometric dating undertaken by the NERC Radiocarbon Laboratory (Grant 550/0993). This financial support is gratefully acknowledged. We also wish to thank L. Vianna, Instituto Nacional de Pesquisas Espaciais, São José dos Campos, Brazil, for instigating the project, provision of Landsat images, and logistical support and comments on this manuscript. Fieldwork was undertaken with the dedicated help of J. B. Neto ('Dedé'), C. Perrin and the fishermen of Touros and Rio do Fogo.

\section{References}

Asmus, H. E. \& Porto, R. 1973. Classificação das bacias sedimentares brasileiras segundo a Tectônica de Placas. Anais: XXVI Congresso Brasileiro de Geologia, 67-90.

Bezerra, F. H. R., Lima-Filho, F. P., Amaral, R. F., Caldes, L. H. O. \& Costa-Neto, L. X. 1998. Holocene coastal tectonics in Northeast Brazil. In: Stewart, I. S. \& Vita-FinzI, C. (eds) Coastal Tectonics. Geological Society, London, Special Publication, 146, 279-293.

Burchette, T. B. \& Wright, V. P. 1992. Carbonate ramp depositional systems. Sedimentary Geology, 79, 3-57.

Doyle, L. J. \& Sparks, T. N. 1980. Sediments of the Mississippi, Alabama and Florida continental shelf. Journal of Sedimentary Petrology, 50, 905-916.

Figueiredo, A. M. F. 1985. Geologia das bacias
Brasileiras. In: Schlumberger (ed.) Avaliação de Formações no Brasil. WEC Brasil, I1-I38.

França, A. M. C., Coutinho, P. N. \& Summerhayes, C. P. 1976. Sedimentos superficiais da margem continental nordeste brasileira. Revista Brasileira de Geociências, 6, 71-89.

Francisconi, O, Costa, M. P. A., Coutinho, M. G. N. \& VICALVI, M. A. 1974. Geologia costeira e sedimentos da plataforma continental brasileira. Anais: $28 .^{\circ}$ Congresso Brasileiro de Geologia, Porto Alegre, 3, 305-321.

HAYES, M. O. 1979. Barrier island morphology as a function of tidal and wave regime. In: LEATHERMAN, S. P. (ed.) Barrier Islands: from the Gulfof St. Lawrence to the Gulf of Mexico. Academic Press, London, 1-28.

JoHnson, H. D. \& BaLdwin, C. T. 1996. Shallow siliciclastic seas. In: READING, H. G. (ed.) Sedimentary Environments: Processes, facies and Stratigraphy. Blackwell Scientific, Oxford, 229-282.

LEES, A. 1975. Possible influence of salinity and temperature on modern shelf carbonate sedimentation. Marine Geology, 19, 159-198.

Light, J. M. \& WiLson, J. B. 1998. Cool-water carbonate deposition on the West Shetland Shelf: a modern distally steepened ramp. This volume.

Logan, B. W., Harding, J. L., Ahr, M., William, J. P. \& SLEEP, R. G. 1969. Carbonate sediments and reefs, Yucatan shelf, Mexico. American Association of Petroleum Geologists, Memoir, 11, 1-198.

Mabesoone, J. M. 1971. Calcários Recentes do litoral nordestino. Estudos Sedimentológicos, 1, 45-54. \& Coutinho, P. N. 1970. Littoral and shallow marine geology of northern and northeastern Brazil. Universidade Federal de Pernambuco. Trabalhos Oceanográficos, 12, 1-214.

Martins, L. R. \& Coutinho, P. N. 1981. The Brazilian continental margin. Earth-Science Reviews, 17, 87-107.

Mello, U. T. 1989. Controles tectônicos na estratigrafia da Bacia Potiguar: uma integração de modelos geodinâmicos. Boletin de Geociências da PETROBRAS, 3, 347-364.

Milliman, J. D. \& Summerhayes, C. P. 1974. Upper continental margin sedimentation off Brazil. Contribuições a Sedimentologia, 4, 1-175.

Mount, J. F. 1984. Mixing of siliciclastic and carbonate sediments in shallow shelf environments. Geology, 12, 432-435.

Mullins, H. T., Gardulski, A. F., Hinchey, E. J. \& Hine, A. C. 1988. The modern carbonate ramp slope of central west Florida. Journal of Sedimentary Petrology, 50, 905-916.

Nelson, C. S., Hancock, G. E. \& Kamp, P. J. J. 1982. Shelf to basin, temperate skeletal carbonate sediments, Three Kings Plateau, New Zealand. Journal of Sedimentary Petrology, 52, 717-732.

READ, J. F. 1985. Carbonate platform facies models. Bulletin, American Association of Petroleum Geologists, 68, 1-21.

RichaRdSON, P. L \& Walsh, D. 1986. Mapping climatological seasonal variation in the surface currents of the tropical Atlantic using ship drifts. Journal of Geophysical Research, 91, 10537-10550. 
Servain, J., SÉva, M. \& Rual, P. 1990. Climatological comparison and long-term variations of sea surface temperature over the tropical Atlantic Ocean. Journal of Geophysical Research, 95, 9421-9431.

SOLEWICS, R. 1989. Feições fisiográficas submarinas da plataforma continental do Rio Grande do Norte visiveis por imagen de satélite. MSc dissertation, Instituto Nacional de Pesquisas Espaciais, São José dos Campos, Brazil.

SouzA, S. Z. 1982. Atualização da litoestratigrafia da Bacia Portiguar. Anais $32^{\circ}$, Congresso Brasiliero do Geologia, Salvador, 5, 2392-2406.

Srivastava, N. K. \& CoRsino, A. R. 1984. Os carbonates de Touros, petrografia e estratigrafia. Anais $11^{\circ}$, Simposioso de Geologia do Nordeste, Natal, Brazil, 165-176.

Suguio, K., BitTencourt, A. C. S. P., Dominguez, J. M. L., FleXor, J. M. \& Azevedo, A. E. G. 1985. Fluctuações do nível relativo de mer durante or Quarternário Superior, ao longo do litoral brasiliero e suas implacações sedimentação costiera. Revista Brasiliera de Geociências, 15, 273-286.

TESTA, V. 1996. Quaternary sediments of the shallow shelf, Rio Grande do Norte, NE Brazil. PhD thesis, Royal Holloway University of London. 1997. Calcareous algae and corals in the inner shelf of Rio Grande do Norte, NE Brazil.
Proceedings 8th International Coral Reef Symposium, Panama, 1, 737-742.

- \& Bosence, D. W. J. in press. Physical and biological controls on the formation of carbonate and siliciclastic bedforms on the Northeast Brazil shelf. Sedimentology.

- Bosence, D. W. J. \& Vianna, M. 1997. Submerged lithologies and their relation with relative sea-level oscillations in Rio Grande do Norte, NE Brazil. VI congresso da ABEQUA e reunião sobre o Quaternario na America do Sul, Curitaba, Pr. Brazil, 155-160.

Vianna, M. L., Solewicks, R., Cabral, A. \& Testa, V. 1991. Sandstream on the northeast Brazilian Shelf. Continental Shelf Research, 2, 509-524.

WILSON, J. B. 1979. Biogenic carbonate sediments on the Scottish continental shelf and on Rockall Bank. Marine Geology, 33, M85-M93.

- 1986. Faunas on tidal current and wave-dominated continental shelves and their use in the recognition of storm deposits. In: KNIGHT, R. J. \& MCLEan, J. R. (eds) Shelf Sands and Sandstones. Canadian Society of Petroleum Geologists, Memoir, II, 313-326.

1988. A model for temporal changes in the faunal composition of shell gravels during a transgression on the continental shelf around the British Isles. Sedimentary Geology, 60, 95-105. 